Murgayanti · A. Nuraini · M. Agtari · A. Karuniawan

\title{
Respons klon ubi jalar (Ipomoea batatas L.) var. Awachy-1 dan var. Biang terhadap aplikasi paclobutrazol
}

\section{Response of sweetpotato clones (Ipomoea batatas L.) var. Awachy-1 and var. Biang to paclobutrazole application}

Diterima : 13 Februari 2018/Disetujui : 19 Desember 2019 / Dipublikasikan : 31 Desember 2019

CDepartment of Crop Science, Padjadjaran University

\begin{abstract}
Paclobutrazol is one type of plant growth regulators that can be used to regulate plant growth with the aim of maintaining the balance of vegetative and generative growth. Each plant genotype would produce a different responses to paclobutrazol. The aimed of this study was to determine the interaction between the concentration of paclobutrazol and two sweet potato clones and to determined the best concentration of paclobutrazol for yield of two sweet potato clones. The experiment was conducted from February to June 2017 at Ciparanje Experimental Station, Faculty of Agriculture, Padjadjaran University, Jatinangor, Sumedang Regency, West Java on 750 m above sea level. Type of rainfall of the experimental area was classified as $\mathrm{C}$ type according to Schmidt and Ferguson. The experiment design used Factorial Randomized Block Design that consisted of two factors and repeated four times. The first factor was sweet potato clone (Biang and Awachy 1) and second factor was the concentration of paclobutrazol $(0,50,100,150$ ppm). The results showed that the number of tubers in Biang produced higher than Awachy 1, and the treatment of paclobutrazol with concentration of $50 \mathrm{ppm}$ had the best yield (weigth of tubers per plant).
\end{abstract}

Keywords: Paclobutrazol $\cdot$ Clone $\cdot$ Sweet potato

Sari. Paclobutrazol merupakan salah satu zat pengatur tumbuh yang dapat digunakan untuk memodifikasi pertumbuhan tanaman dengan cara mempertahankan keseimbangan pertumbuhan vegetatif dan generatif. Setiap genotipe tanaman akan menghasilkan respons yang berbeda

Dikomunikasikan oleh Aep Wawan Irwan dan Sumadi

Departemen Budidaya Pertanian, Fakultas Pertanian,

Universitas Padjadjaran, Bandung

Korespondensi: agung.karuniawan@unpad.ac.id terhadap pemberian paclobutrazol. Penelitian ini bertujuan untuk mengetahui interaksi antara konsentrasi paclobutrazol dengan dua klon ubi jalar serta mengetahui konsentrasi paclobutrazol yang terbaik untuk pertumbuhan dan hasil dua klon ubi jalar. Percobaan dilakukan pada bulan Februari sampai Juni 2017 di kebun Percobaan Ciparanje, Fakultas Pertanian Universitas Padjadjaran, Jatinangor, Kabupaten Sumedang, Jawa Barat pada ketinggian $750 \mathrm{~m}$ dpl. Jenis tanah tempat percobaan adalah Inceptisol, tipe curah hujan $\mathrm{C}$ menurut menurut klasifikasi Schmidt dan Ferguson bertipe C (agak basah). Percobaan menggunakan Rancangan Acak Kelompok (RAK) pola faktorial yang terdiri dari dua faktor dan diulang sebanyak empat kali. Faktor pertama yaitu klon ubi jalar (Awachy 1 dan Biang) dan faktor kedua yaitu konsentrasi paclobutrazol $(0,50,100$, 150 ppm). Hasil penelitian menunjukkan klon Biang menghasilkan jumlah ubi per tanaman yang lebih tinggi daripada klon Awachy 1. Konsentrasi paclobutrazol $50 \mathrm{ppm}$ menghasilkan bobot ubi per tanaman yang lebih tinggi.

Kata kunci: Paclobutrazol • Klon • Ubi jalar.

\section{Pendahuluan}

Ubi jalar (Ipomoea batatas L.) merupakan salah satu tanaman pangan yang bergizi karena mengandung serat, beta karoten, dan vitamin $\mathrm{C}$ yang cukup tinggi (Brandenberger et al., 2015). Produktivitas ubi jalar pada tahun 2017 mencapai 18,36 ton, padahal potensi hasil ubi jalar bisa mencapai 30 ton ha $^{-1}$ (Kementan, 2018). Rendahnya produktivitas ubi jalar dari potensi hasil serta menurunnya angka produksi menjadi salah satu masalah yang dihadapi dalam kegiatan usaha tani ubi jalar (Litbang Pertanian, 2011). 
Produktivitas ubi jalar sangat bergantung pada jumlah dan laju asimilat dari tajuk ke bagian bawah tanaman. Jika pertumbuhan tajuk lebih besar akan mengakibatkan ubi menjadi kecil (Pulungan et al., 2017). Pemberian zat pengatur tumbuh dapat dilakukan untuk memodifikasi pertumbuhan tanaman secara fisiologis, yaitu dengan mengatur pertumbuhan vegetatif dan generatif. Paclobutrazol merupakan salah satu zat pengatur tumbuh dari jenis retardan yang mampu meningkatkan transportasi asimilat ke bagian akar sehingga dapat meningkatkan hasil melalui aksi penghambatan biosintesis giberelin (Lakshmana et al., 2007 ; Mansuroglu et al., 2009).

Kendala lain yang ditemukan dalam produksi ubi jalar adalah pembentukan ubi yang tidak konsisten pada setiap tanaman karena setiap inidividu memiliki hasil yang berbeda. Hal tersebut berkaitan dengan adanya faktor genetik. Klon yang digunakan pada penelitian ini terdiri dari dua tipe pertumbuhan yang berbeda, yaitu klon dari varietas Biang dan Klon dari varietas Awachy 1. Variasi tumbuh yang berbeda pada kedua klon menyebabkan proses fisiologis di dalam tanaman yang berbeda, termasuk respons tanaman terhadap pemberian zat pengatur tumbuh jenis paclobutrazol pun berbeda. Hal ini sesuai dengan pendapat Loebenstein \& Thottappilly (2009) yang menyatakan bahwa mekanisme genetik menjadi dasar faktor-faktor yang mendorong pembentukan akar penyimpanan. Oleh karena itu, dibutuhkan konsentrasi paclobutrazol yang tepat untuk pertumbuhan optimal dari setiap klon ubi jalar. Berdasarkan hal tersebut, maka perlu dikaji interaksi antara pemberian beberapa konsentrasi paclobutrazol dan penggunaan klon ubi jalar Biang dan Awachy 1 terhadap pertumbuhan dan hasil tanaman.

Penelitian ini bertujuan untuk menetapkan konsentrasi paclobutrazol terbaik untuk pertumbuhan dan hasil dua klon ubi jalar baru Unpad.

\section{Bahan dan Metode}

Penelitian dilakukan di kebun Percobaan Ciparanje, Fakultas Pertanian Universitas Padjadjaran, Jatinangor, Sumedang, Jawa Barat. Lokasi percobaan berada di ketinggian 750 meter di atas permukaan laut. Percobaan dilakukan pada bulan Februari 2017 hingga Juni 2017.
Bahan-bahan yang digunakan dalam penelitian ini meliputi bahan tanam setek klon Biang dan Awachy 1 dengan panjang $25 \mathrm{~cm}$. Penanaman dilakukan pada guludan yang mempunyai lebar $70 \mathrm{~cm}$, tinggi $30 \mathrm{~cm}$, dan panjang $5 \mathrm{~m}$. Pupuk yang digunakan yaitu pupuk kandang (10 t ha-1), Urea (200 kg ha-1), SP-36 (100 kg ha-1), dan KCl (100 kg ha-1). Zat pengatur tumbuh yang digunakan ialah paclobutrazol. Alat-alat yang digunakan adalah cangkul, emrat, patok kayu, label, spidol, gunting, alat ukur meteran, timbangan, sprayer, karung, kantong plastik, map kertas dan software analisis data SPSS.

Percobaan menggunakan Rancangan Acak Kelompok pola faktorial yang terdiri dari dua faktor. Faktor pertama yaitu klon ubi jalar (K) yang terdiri dari dua taraf (Awachy-1 dan Biang) dan faktor kedua yaitu konsentrasi paclobutrazol $(\mathrm{P})$ yang terdiri dari empat taraf $(0,50,100,150$, dan 200 ppm). Setiap kombinasi perlakuan diulang empat kali sehingga diperoleh 32 satuan percobaan. Satuan percobaan terdiri dari 3 guludan yang ditanami 20 tanaman pada setiap guludan sehingga terdapat 60 tanaman per petak. Total tanaman ubi jalar yang digunakan adalah 1920 tanaman. Penyemprotan paclobutrazol melalui daun dilakukan pada umur 5 minggu setelah tanam.

\section{Hasil dan Pembahasan}

Jumlah Ubi per tanaman. Pembentukan ubi terjadi karena adanya proses diferensiasi akar yang terjadi akibat penimbunan asimilat dari daun yang membentuk ubi. Hasil analisis menunjukkan tidak terdapat interaksi antara faktor klon dan konsentrasi paclobutrazol terhadap jumlah ubi/tanaman, namun secara mandiri terdapat pengaruh yang nyata pada faktor klon ubi jalar (Tabel 1).

Klon Biang memiliki jumlah ubi lebih banyak daripada klon Awachy 1. Hal ini menunjukkan bahwa faktor genetik sangat berpengaruh terhadap jumlah ubi. Ravi et al. (2009) menyatakan bahwa semua proses pembentukan ubi dikendalikan oleh fitohormon endogen dan ekspresi yang dikendalikan oleh gen yang berbeda.

Bobot ubi/tanaman. Bobot ubi per tanaman berdasarkan hasil analisis statistik tidak dipengaruhi oleh interaksi antara klon dan konsentrasi paclobutrazol 
Tabel 1. Pengaruh mandiri klon ubi jalar dan konsentrasi paclobutrazol terhadap jumlah ubi per tanaman.

\begin{tabular}{ll}
\hline Perlakuan & $\begin{array}{l}\text { Jumlah ubi per tanaman } \\
\text { (buah) }\end{array}$ \\
\hline Klon (K) & \\
k1 (Awachy 1) & $2,04 \mathrm{a}$ \\
k2 (Biang) & $3,60 \mathrm{~b}$ \\
\hline Konsentrasi & \\
Paclobutrazol (P) & \\
p1 (0 ppm) & $2,46 \mathrm{a}$ \\
p2 (50 ppm) & $2,96 \mathrm{a}$ \\
p3 (100 ppm) & $3,08 \mathrm{a}$ \\
p4 (150 ppm) & $2,79 \mathrm{a}$ \\
\hline
\end{tabular}

Keterangan : Nilai rata-rata yang diikuti huruf yang sama pada kolom yang sama menunjukkan tidak berbeda nyata pada taraf nyata $5 \%$ menurut uji Jarak Berganda Duncan.

Tabel 2. Pengaruh mandiri klon ubi jalar dan konsentrasi paclobutrazol terhadap bobot ubi per tanaman ubi jalar.

\begin{tabular}{ll}
\hline Perlakuan & $\begin{array}{l}\text { Bobot ubi per } \\
\text { tanaman }(\mathrm{g})\end{array}$ \\
\hline Klon (K) & \\
k1 (Awachy 1) & $370,938 \mathrm{a}$ \\
k2 (Biang) & $453,494 \mathrm{a}$ \\
\hline Konsentrasi Paclobutrazol (P) \\
p1 (0 ppm) \\
p2 (50 ppm) & $337,500 \mathrm{a}$ \\
p3 (100 ppm) & $403,438 \mathrm{~b}$ \\
p4 (150 ppm) & $530,313 \mathrm{~b}$ \\
\hline
\end{tabular}

Keterangan : Nilai rata-rata yang diikuti huruf yang sama pada kolom yang sama menunjukkan tidak berbeda nyata pada taraf nyata $5 \%$ menurut uji Jarak Berganda Duncan.

Konsentrasi paclobutrazol berpengaruh nyata terhadap bobot ubi per tanaman (Tabel 2). Bobot ubi per tanaman mengalami peningkatan setelah dilakukan aplikasi paklobutrazol. Peningkatan bobot ubi terjadi karena pengurangan sink pada organ vegetatif seperti penurunan panjang batang sehingga energi akan terfokus pada organ ubi dan bobot ubi yang dihasilkan akan meningkat (Balmani and Poovaiah, 1985).

Perlakuan paclobutrazol pada tanaman ubi dapat meningkatkan bobot ubi yang dihasilkan. Hal ini disebabkan karena paclobutrazol dapat menurunkan tingkat giberelin yang menyebabkan penurunan kinerja fisiologis tanaman serta memicu tanaman untuk mengalokasikan energi pada ubi sehingga hasil ubi lebih tinggi (Esmaielpour et al., 2011)

Indeks Panen. Hasil uji F pada parameter indeks panen menunjukkan bahwa tidak terdapat interaksi antara klon ubi jalar dan pemberian paclobutrazol terhadap indeks panen.

Tabel 3. Pengaruh mandiri klon ubi jalar dan konsentrasi paclobutrazol terhadap indeks panen tanaman ubi jalar.

\begin{tabular}{lc}
\hline Perlakuan & Indeks Panen \\
\hline Klon (K) & \\
k1 (Awachy 1) & 0,3704 a \\
k2 (Biang) & $0,4485 \mathrm{a}$ \\
\hline Konsentrasi Paclobutrazol $(\mathrm{P})$ & \\
p1 $(0$ ppm) & $0,3914 \mathrm{a}$ \\
p2 (50 ppm) & $0,406 \mathrm{a}$ \\
p3 (100 ppm) & $0,4692 \mathrm{a}$ \\
p4 (150 ppm) & $0,3712 \mathrm{a}$ \\
\hline
\end{tabular}

Keterangan : Nilai rata-rata yang diikuti huruf yang sama pada kolom yang sama menunjukkan tidak berbeda nyata pada taraf nyata 5\% menurut uji Jarak Berganda Duncan.

Pada pengaruh mandiri klon (Tabel 3), terlihat bahwa klon Biang memiliki hasil panen yang lebih tinggi namun tidak berbeda nyata dengan klon Awachy 1. Pengaruh mandiri konsentrasi paclobutrazol tidak memperlihatkan adanya perbedaan yang nyata antar perlakuan.

Pada Tabel 3 terlihat bahwa indeks panen dari ubi jalar dari hasil percobaan ini adalah 0,37 - 0,47. Bhagsari et al. (1990) mengemukakan bahwa indeks panen dari ubi jalar ialah sebesar 0,3-0,75. Indeks panen menurut Rosyadi dkk. (2014) didefinisikan sebagai proporsi dari berat umbi segar dalam biomassa. Parameter ini mencer-minkan distribusi kandungan bahan kering yang mendukung produksi hasil umbi. Nilai indeks panen tinggi menunjukkan klon tersebut mampu mendistribusikan asimilat lebih banyak ke dalam umbi.

\section{Kesimpulan}

Tidak terdapat interaksi antara klon ubi jalar dengan konsentrasi paclobutrazol. Klon Biang memiliki jumlah ubi/tanaman yang lebih tinggi daripada klon Awachy 1. Konsentrasi paclobutrazol 50 ppm menghasilkan bobot ubi/tanaman yang lebih tinggi pada ubi jalar. 


\section{Ucapan Terima Kasih}

Terima kasih kepada Kemenristekdikti yang telah mendanai penelitian ini melalui Skema Penelitian Unggulan Strategis Nasional (PUSNAS) tahun 2017, a.n. Dr (Sc.) Agung Karuniawan.

\section{Daftar Pustaka}

Balamani, V., and L. B. W. Poovaiah. 1985. Retardation of shoot growth and promotion of tuber growth of potato plants by paclobutrazol. American Potato Journal, 62(7): 363-369.

Bhagsari, A.S., and D.A. Ashley. Relationship of Photosynthesis and Harvest Index to Sweet Potato Yield. Journal of American Society for Horticultural Science. 115:288-293

Brandenberger, L., S. James, R. Eric, and D. John. 2015. Sweet potato production. Oklahoma State University. HLA-6022.

Esmaielpour, B., S. Hokmalipour, P. Jalilvand, and G. Salimi. 2011. The investigation of paclobutrazol effects on growth and yield of two potato (Solanum tuberosum) cultivars under different plant density. Journal of Food, Agriculture, \& Environment, 9(3\&4): 289-294.

Kementan, 2018. Data Lima Tahun Terakhir. https://www.pertanian.go.id. Diakses tanggal 6 Desember 2019.
Lakshmana, and B.A. Rehiman. 2007. Effect of different levels of $\mathrm{pH}$ and culture on quality of Kokum (Garcinia indica) Fruit Wine. Environment and Ecology. 25 : 973977.

Litbang Pertanian. 2011. Kajian Keterkaitan Produksi, Perdagangan dan Konsumsi Ubi Jalar Untuk Meningkatkan 30\% Partisipasi Konsumsi Mendukung Program Penganekaragaman Pangan dan Gizi. Badan Penelitian dan Pengembangan Pertanian Kementerian Pertanian.

Loebenstein, G., and Thottappilly, G. 2009. The Sweet Potato. Springer Science \& Business Media B.V.

Mansuroglu, S., O. Karaguzel, V. Ortacesme and M. Sayan, 2009. Effect of paclobutrazol on flowering, leaf and flower colour of Consolida orientalis. Pakistan Journal of Botany 41 : 2323-2332.

Pulungan, A.S., R.R Lahay, dan E. Purba. 2017. Pengaruh Waktu Pemberian dan Konsentrasi Paklobutrazol terhadap Pertumbuhan dan Produksi Tanaman Ubi Jalar (Ipomoea batatas L.). Jurnal Agroteknologi. 5(3) : 716-721.

Ravi, V., S.K. Naskar, T. Makeshkumar, B. Babu, and B.S.P. Krishnan. 2009. Molecular physiology of storage root formation and development in sweet potato (Ipomoea batatas (L.) Lam.). J. Root Crops 35:1-27.

Rosyadi, M.I, Toekidjo, dan Supriyanta. 2014. Karakterisasi Ubikayu Lokal (Manihot utilissima L.) Gunung Kidul. Vegetalika . 3(2): $59-71$. 